\title{
Shear wave velocity structure beneath Bandung basin, West Java, Indonesia from ambient noise tomography
}

\author{
B. Pranata, ${ }^{1,2}$ T. Yudistira, ${ }^{3}$ S. Widiyantoro ${ }^{\oplus},{ }^{3}$ B. Brahmantyo, ${ }^{4}$ P.R. Cummins,${ }^{5}$ \\ E. Saygin, ${ }^{6,7}$ Z. Zulfakriza, ${ }^{3}$ S. Rosalia ${ }^{\oplus 3,8}$ and A. Cipta ${ }^{9}$ \\ ${ }^{1}$ Study Program of Earth Sciences, Faculty of Earth Science and Technology, Institut Teknologi Bandung, Jl. Ganesha No. 10, Bandung 40132, Indonesia \\ ${ }^{2}$ Agency for Meteorology, Climatology and Geophysics (BMKG), Jakarta 10720, Indonesia \\ ${ }^{3}$ Global Geophysics Research Group, Faculty of Mining and Petroleum Engineering, Institut Teknologi Bandung, Jalan Ganesha No. 10, Bandung 40132, \\ Indonesia.E-mail: sriwid@geoph.itb.ac.id \\ ${ }^{4}$ Applied Geology Research Group, Faculty of Earth Science and Technology, Institut Teknologi Bandung, Jl. Ganesha No. 10, Bandung 40132, Indonesia \\ ${ }^{5}$ Research School of Earth Sciences, Australian National University, Canberra, ACT 2601, Australia \\ ${ }^{6}$ Deep Earth Imaging Future Science Platform, CSIRO, Australian Resources Research Centre, 26 Dick Perry Avenue, Kensington, WA 6151, Western Australia \\ ${ }^{7}$ Department of Physics, School of Physics, Mathematics and Computing, Faculty of Engineering and Mathematical Sciences, University of Western \\ Australia, Perth, WA 6009, Australia \\ ${ }^{8}$ Graduate Program of Geophysical Engineering, Faculty of Mining and Petroleum Engineering, Institut Teknologi Bandung, Jl. Ganesha No. 10, Bandung \\ 40132, Indonesia \\ ${ }^{9}$ Center for Volcanology and Geological Hazard Mitigation, Geological Agency, Bandung 40122, Indonesia
}

Accepted 2019 October 26. Received 2019 October 20; in original form 2019 February 8

\begin{abstract}
SUMMAR Y
We investigated the seismic shear wave velocity structure of the upper crust beneath the Bandung area in West Java, Indonesia, using ambient seismic noise tomography. We installed 60 seismographs to record ambient seismic noise continuously in the city of Bandung and its surrounding area for 8 months. After interstation cross-correlation of recordings of ambient seismic noise, we obtained empirical Green's functions for Rayleigh waves. Group velocity dispersion curves for Rayleigh waves between periods of 1 and $8 \mathrm{~s}$ were measured on each interstation path by applying the multiple filter analysis method with phase-matched processing. The spatial variation of group velocities shows a good correlation with the geological structure of the Bandung Basin. The Rayleigh wave dispersion maps were inverted to obtain the 1-D shear wave velocity profiles beneath each station, which were interpolated to infer a pseudo-3-D structure under the study region. The results show that the Bandung Basin has a thick layer of sediment. Along the northern, eastern and southern mountains surrounding the Bandung Basin there is high-velocity structure, except to the west of the Tangkuban Parahu volcano, where a massive low-velocity structure extending throughout the upper crust might indicate the presence of fluids or partial melts.
\end{abstract}

Key words: Asia; Basin; Tomography; Crustal Structure.

\section{INTRODUCTION}

As recently as a decade ago, ambient seismic noise was regarded as a nuisance that needed to be removed by signal processing. However, since seismologists learned how to extract Green's functions (GFs) from the cross-correlation of ambient seismic noise, this method has become a mainstay for estimating seismic velocity structure beneath Earth's surface.

Southern California was the first region where a seismic velocity tomographic map was derived from ambient noise data (Sabra et al. 2005; Shapiro et al. 2005). Since then many ambient noise tomography-related studies have been published (e.g. Kang \& Shin 2006; Yang et al. 2007; Bensen et al. 2008; Li et al. 2009, 2010;
Saygin \& Kennett 2010, 2012; Zulfakriza et al. 2014; Martha et al. 2017, and many others).

In this study, we used ambient noise tomography (ANT) to image the subsurface structure of Bandung, West Java and its surroundings. ANT has been often used to estimate subsurface seismic velocity structure and particularly the thickness of sediment (e.g. Lin et al. 2008). ANT has also been used previously to estimate crustal structure at several locations in Indonesia, including Lake Toba (Stankiewcs et al. 2010), central Java (Zulfakriza et al. 2014) and East Java and Bali (Martha et al. 2017). Our study closely resembles the Jakarta Basin study of Saygin et al. (2016), where a relatively close station spacing of a few $\mathrm{km}$ is used to image details of basin structure. 


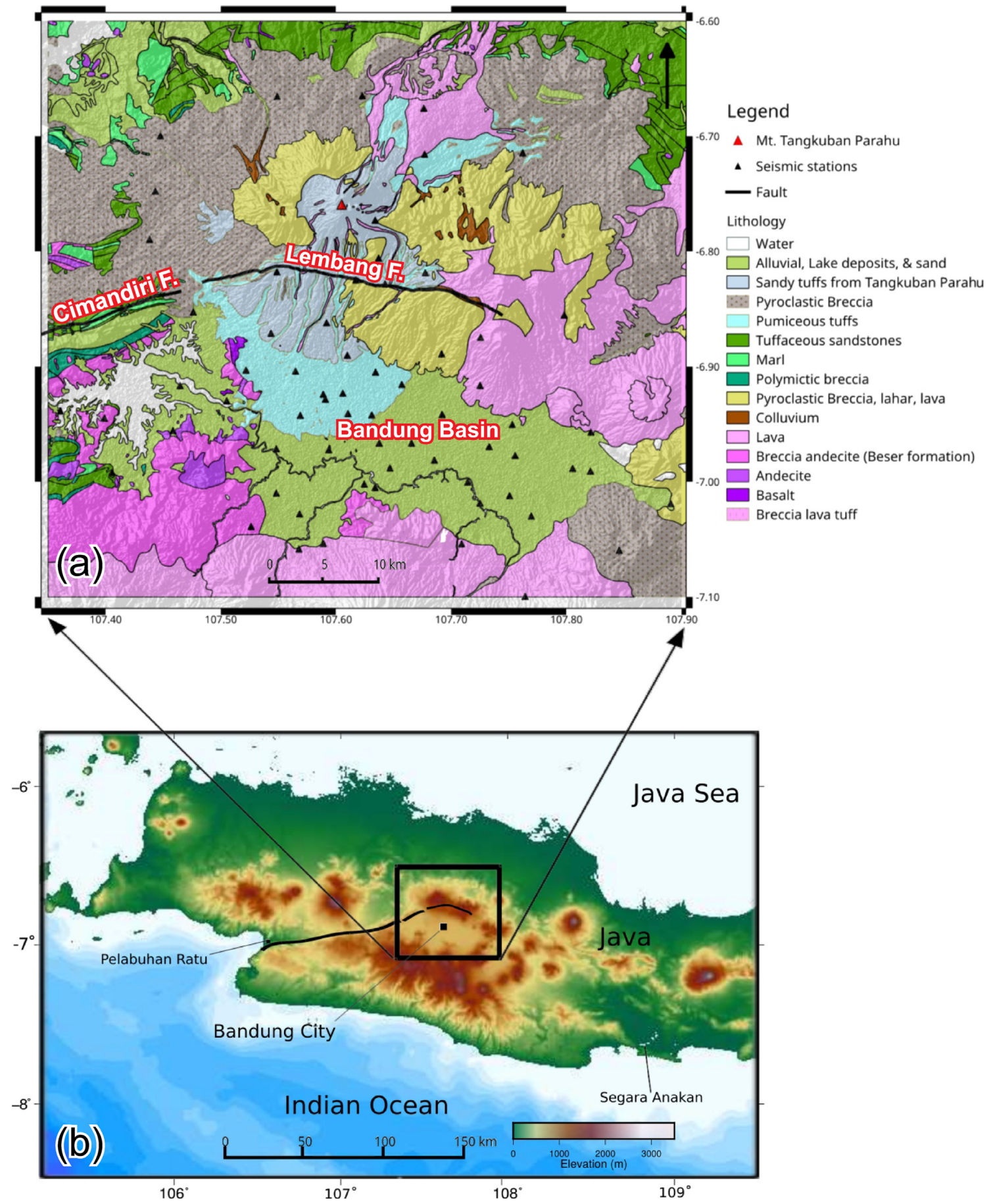

Figure 1. (a) Map of geological features (modified and compiled from Silitonga 1973, Alzwar et al. 1992 and Sujatmiko 1972) of the study area, including the distribution of seismic stations (black triangles) that were operated around the Bandung Basin, and a red triangle that indicates the Tangkuban Parahu volcano. The sensor type we used is Trillium Compact 120s. The data will be publicly available after this publication. (b) An index map with the location of the study area indicated by the black box.

\section{GEOLOGICAL SETTING}

The Bandung Basin area, the focus of this study, is located in West Java, Indonesia, where the Australian plate is subducting beneath the Eurasian Plate along the Java Trench. According to Van Bemmelen (1949), the Bandung Basin is located in the Bandung zone, an area of low relief surrounded by mountains (an intermontagne depression, see Fig. 1a). This zone has a curved shape from Pelabuhan Ratu following the continuous Cimandiri Valley to the east through northern Bandung, and ends at Segara Anakan at the mouth of the Citanduy River (Fig. 1b), with a zone width of 20-40 km. In the Bandung zone, there are several elevations consisting of Late Tertiary and Quaternary volcanic terrains that appear among young volcanic deposits. The volcanoes comprise topographic highs along the edge the Bandung zone, on the border of the Bogor zone and the Southern Mountains zone. Van Bemmelen (1949) states that many geological events were dominated by volcanic activity during the 


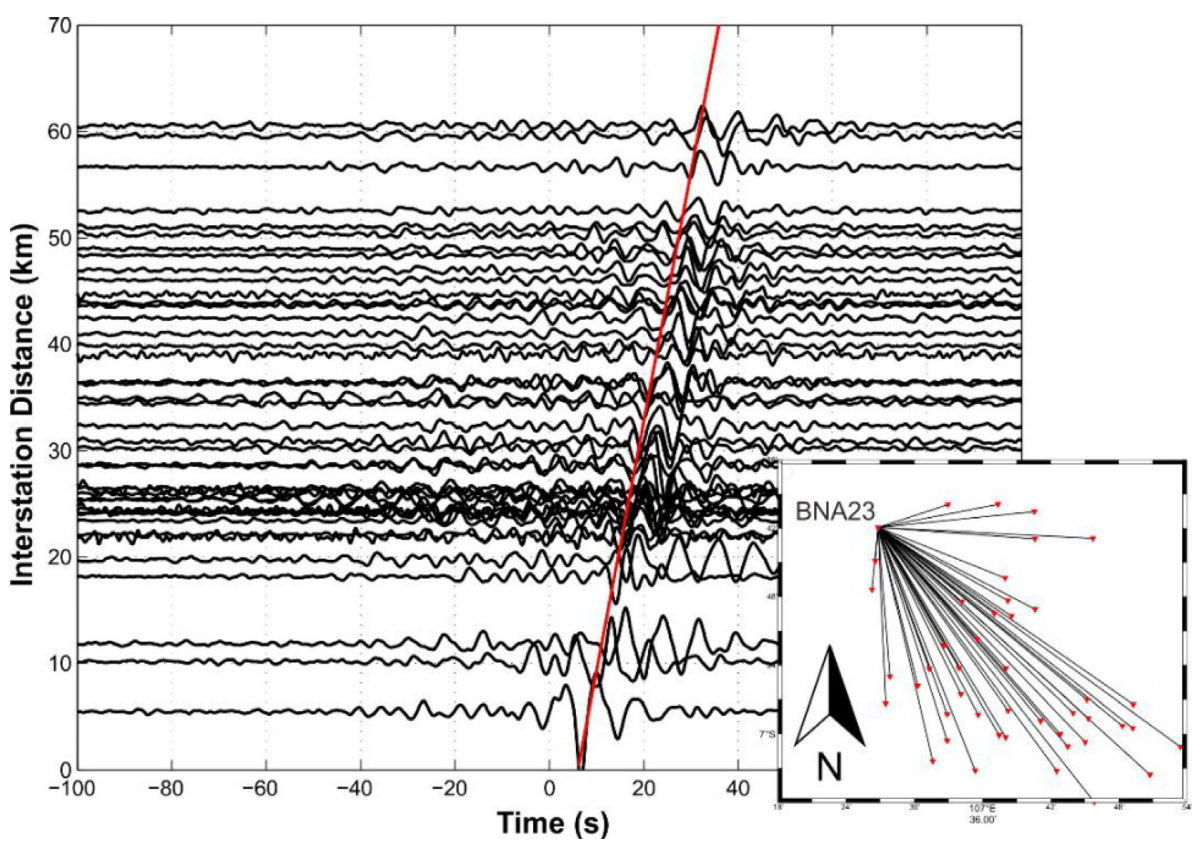

Figure 2. Interstation correlograms of ambient seismic noise estimates used to estimate point source Green's functions between station BNA23 on the northwestern edge of the network and other stations. Waveforms were filtered between 0.125 and $1.0 \mathrm{~Hz}$. The time length of cross-correlation extends from 0 to $100 \mathrm{~s}$. Red line depicts group velocity of $\sim 2.3 \mathrm{~km} \mathrm{~s}^{-1}$, and used as reference time to window dispersive train segment.

Quaternary, so that the surface geology is dominated by volcanic products. Van Bemmelen (1949) also suggests that the initiation of the Lembang Fault, which skirts the northern edge of Bandung, cannot be separated from the evolution of the Bandung Basin. Suhari \& Siebenhuner (1993) explain the lithology of the Bandung Basin as dominated by Quaternary volcanic rocks comprised of andesite to dacitic lava, breccia, agglomerate, tuff, lava and intrusive igneous rocks (Fig. 1). The western part of the basin is dominated by Tertiary sediments consisting of sandstone, claystone and limestone with young alluvium and fluvial sediments derived from volcanic deposits scattered in the middle of the basin.

According to Bronto \& Hartono (2006), there are four possible explanations for the formation of the Bandung Basin, as: (1) a large intramountain basin formed by exogenous processes as explained by Dam (1994) and Dam et al. (1996); (2) a graben, that is the result of tectonic deformation alone; (3) a caldera, i.e. a product of volcanic processes alone or (4) a volcano-tectonic caldera, resulting from a combination of tectonic and volcanic processes. However, other researchers believe that the Bandung Basin is a half-graben (e.g. Van Bemmelen 1949; Dam 1994).

\section{DATA PROCESSING}

In this study, we analysed continuous vertical component seismic waveform data recorded at 60 seismograph stations from the Bandung Seismic Experiment installed from March to October 2014. The distribution of seismographic station locations in the study area is shown in Fig. 1(a). We followed the steps outlined in Saygin \& Kennett (2010) in processing the ambient seismic noise signals. The data were windowed in 2-hr segments and band-pass filtered between 0.01 and $1 \mathrm{~Hz}$. After that, we arranged each station-pair so as to regard the first station as the event source and the second station as the receiver before waveform cross-correlation and stacking. We obtained more than 1569 interstation cross-correlations, each of which is assumed to be dominated by the fundamental-mode Rayleigh wave.

In order to facilitate estimation of the fundamental-mode Rayleigh wave group velocity, we conducted manual picking and windowing of the Rayleigh wave using bandpassed-filtered crosscorrelated signals. Fig. 2 shows an example of such correlograms filtered between 0.125 and $1 \mathrm{~Hz}$ (or period range 1-8 s), arranged with station BNA23 as a reference to other stations. The crosscorrelogram was measured by cross-correlating the time series data from a station located to the north relative to most of the other stations, and showing a prominent arrival which we interpret to be the Rayleigh wave propagating away from the noise source that appears to be concentrated in the north relative to the network. This result is consistent with our previous result using different data set from Central Java (Yudistira \& Widiyantoro 2016). In order to extract dispersive curves, windowing of the cross-correlated signals was conducted using a width of $16 \mathrm{~s}$, that is $8 \mathrm{~s}$ before and after the picked time. The picked time is a time estimated as the arrival time of dispersive wave, in Fig. 2 chosen near the intersection between the red line and time axis of each cross-correlation. The minimum distance between stations whose cross correlations give clear dispersive wavetrains is $5 \mathrm{~km}$ and the maximum distance is $60 \mathrm{~km}$ (BNA23-BNA36). We refer to the windowed cross correlation as the emperical Green's functions (EGFs).

We selected and cropped EGFs with the highest signal to noise ratio among either the positive or negative lag. The number of EGFs that could be picked or windowed was 1546. The next step was the measurement of group velocity dispersion using the multiplefilter technique, with a phase-matching process to isolate the fundamental-mode Rayleigh wave (Herrmann 1973). We manually checked the quality of all group velocity dispersion curves over a period range between 1 and $8 \mathrm{~s}$. We plotted all obtained group velocity curves to identify the general pattern of a smooth variation in group velocity with period, and rejected or cropped the frequency band of curves where they deviated dramatically from the general trend. 


\section{GROUP VELOCITY TOMOGRAPHY}

We inverted the interstation group delay times to obtain Rayleigh wave group velocity tomograms, for period range 1-8 s, using the subspace method of Kennett et al. (1988), which uses the fast marching method (FMM, Rawlinson \& Sambridge 2004a,b) for tracing the surface wave ray paths. This grid-based eikonal solver is particularly stable in the kind of strongly heterogeneous media we expect to encounter in the Bandung Basin. Although the ray bending in the estimation of the group velocities cannot be exactly computed from the group velocity maps, it is expected to have some level of correlation between group and phase velocities. Therefore it is acceptable to use bending rays rather than straight ray approximation. Keeping in mind the limitation of checkerboard tests as introduced by Lévêque et al. (1993), we conducted these tests to evaluate the lateral resolution of the Rayleigh wave group velocity maps resulting from tomographic inversion. These checkerboard tests were performed using the ray path coverage obtained with the data from the Bandung Seismic Experiment at different periods. Fig. 3 shows the results of checkerboard tests at periods of 1-8 s using a grid size of $0.80^{\circ} \times 0.70^{\circ}$ with a maximum velocity perturbation of $1.15 \mathrm{~km} \mathrm{~s}^{-1}$, a damping value of 200 and a smoothing parameter of 200 (see eq. 2 of Saygin \& Kennett 2010). In general, the checkerboard pattern is recovered where the ray path coverage is good, particularly in the Bandung Basin. The checkerboard pattern is not as well recovered outside the basin where the ray path coverage is sparse (Fig. S2 shows the Rayleigh ray path coverage at periods 1-8 s).

Surface waves are dispersive: the longer the period, the deeper the wave energy penetrates into the subsurface structure. Rayleigh waves at longer periods therefore have more sensitivity to deeper structure. The fundamental-mode Rayleigh wave group velocity maps we obtained at periods $1-8 \mathrm{~s}$ are shown in Fig. 4. This period span $(\leq 8 \mathrm{~s})$ of the Rayleigh wave group velocity is most sensitive to the shear velocity in the upper crust because the Rayleigh wave energy at these periods is largely concentrated there. In the group velocity maps, low group velocities were observed clearly under the Bandung Basin. The area outside the basin is generally characterized by higher group velocity, except in the northwestern part of the study area, in which a very low group velocity is observed to the west of Mt Tangkuban Parahu, an active volcano in the study area.

The tomographic images of Rayleigh wave group velocity correlate well with the topography and surface geology. The basin has a flat topography typical of poorly consolidated sediments with low shear velocity (Wald \& Allen 2007), while the surrounding areas of higher relief are characterized by higher group velocities. We note that within the Bandung Basin there are two distinct zones of low Rayleigh group velocity, that is in the western and eastern parts of the Bandung Basin, and a small patch of high group velocity divides these two low group velocity zones. As discussed in more detail below, these likely reflect the different depositional and erosional processes involved in the development of the landscape.

\section{SHEAR WAVE VELOCITY STRUCTURE}

The Rayleigh wave group velocity maps estimated as described in the previous section were used in the inversion for shear velocity $(V s)$ structure estimation in and around the Bandung Basin. At each point of a regular grid covering the study area at $0.05^{\circ}(\sim 5.5 \mathrm{~km})$ spacing, the dispersion curve was calculated by interpolating over the maps covering the period range $1-8 \mathrm{~s}$. The dispersion curve at each point was then inverted using the Dinver software (Wathelet et al. 2008) that incorporates the forward modelling algorithm of
Dunkin (1965) and the Neighbourhood Algorithm (NA) of Sambridge (1999a,b) for inversion of the dispersion curves to obtain 1-D profiles.

In the NA inversion, we constrained the deepest layers of each $V p$ and $V s$ model using the AK135 model (Kennett et al. 1995), so that the maximum limit for $V p$ and $V s$ at depths of $0-10 \mathrm{~km}$ is 6.0 and $3.4 \mathrm{~km} \mathrm{~s}^{-1}$, respectively. The NA algorithm considered 4layer models and variations of the thickness and velocities at the top and bottom of each of 4-layers, where each layer consists of 5 evenly spaced sublayers having constant velocity determined by linearly interpolating the top and bottom velocities of the corresponding layer. This parametrization can result in depth profiles containing 'staircase-like' detail that is not well constrained by the smooth Rayleigh wave group velocity dispersion curves considered here; we refrain from interpreting such complex structure and instead focus on the larger-scale trends in velocity that better reflect the information content of the data.

In total there are $2701-\mathrm{D} V s$ profiles in the study area and these will be combined to create 3-D $V s$ distribution. Fig. S4 shows the positions of these profiles and the inverted $V s$ profiles for selected points across the Bandung Basin, for depths down to $10 \mathrm{~km}$. These 1-D profiles have a sharp increase in $V s$ at about $400 \mathrm{~m}$ and $2.2 \mathrm{~km}$ depth, which may indicate the base of sedimentary basin fill and older volcanic deposits, respectively.

Like the Rayleigh wave group velocity tomograms in Fig. 4, the $V s$ tomograms in Fig. S5 show relatively high velocity zones surrounding the Bandung Basin, except to the west of Mt Tangkuban Parahu. These high velocity zones generally become stronger and more widespread with increasing depth, with the exception of the Tangkuban Parahu anomaly, This is most clearly illustrated in the pseudo-3-D Vs model of the upper crust beneath Bandung generated by interpolating the $2701-\mathrm{D} V s$ profiles. Cross-sections of this model are shown in Fig. 5, where it can be seen that the western Bandung Basin corresponds to a strong low- $V s$ anomaly at very shallow depth $(<1 \mathrm{~km})$, while the eastern basin is weaker and more shallow (Figs $5 \mathrm{a}$ and $\mathrm{c}$ ). The low- $V s$ anomaly associated with Tangkuban Parahu, on the other hand, becomes stronger and more pervasive with depth, dominating the cross-section B-B' in Fig. 6(b). Fig. 6(c) also shows distinct low- $V s$ anomalies below the Bandung Basin at about 5 and $10 \mathrm{~km}$ depth.

\section{DISCUSSION}

In Fig. 6 it is shown that some parts of the study region have a strong spatial correspondence between the $V s$ map at shallow depth $(1.0 \mathrm{~km})$ and the surface geology of the Bandung Basin and its surroundings. Here, we compare three zones indicated by dashed Ellipses 1-3 in Fig. 6 with the geological features in the study area. The tomogram clearly depicts the existence of a high velocity zone extending in the north-south direction (Ellipse 1) that separates the Bandung Basin into two sub-basins. This high velocity zone suggests that the basement depth is shallow between the two subbasins, which is in agreement with the relatively high topographic relief. This anomaly is not explained by the surface geological map, which indicates that most of the area in Ellipse 1 is covered by sediment. However, the surface geology map shows that the Beser formation of andesitic breccia of Pliocene-age (Koesmono et al. 1996; see Fig. 1a, light purple colour) covers most of the region south of Bandung, including the southern portion of Ellipse 1. A minor outcrop of the Beser formation also appears on the northern edge of Ellipse 1 in Fig. 6. We therefore surmise that the Beser 


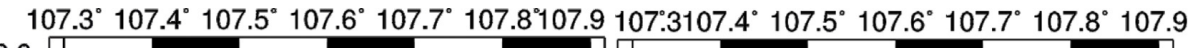
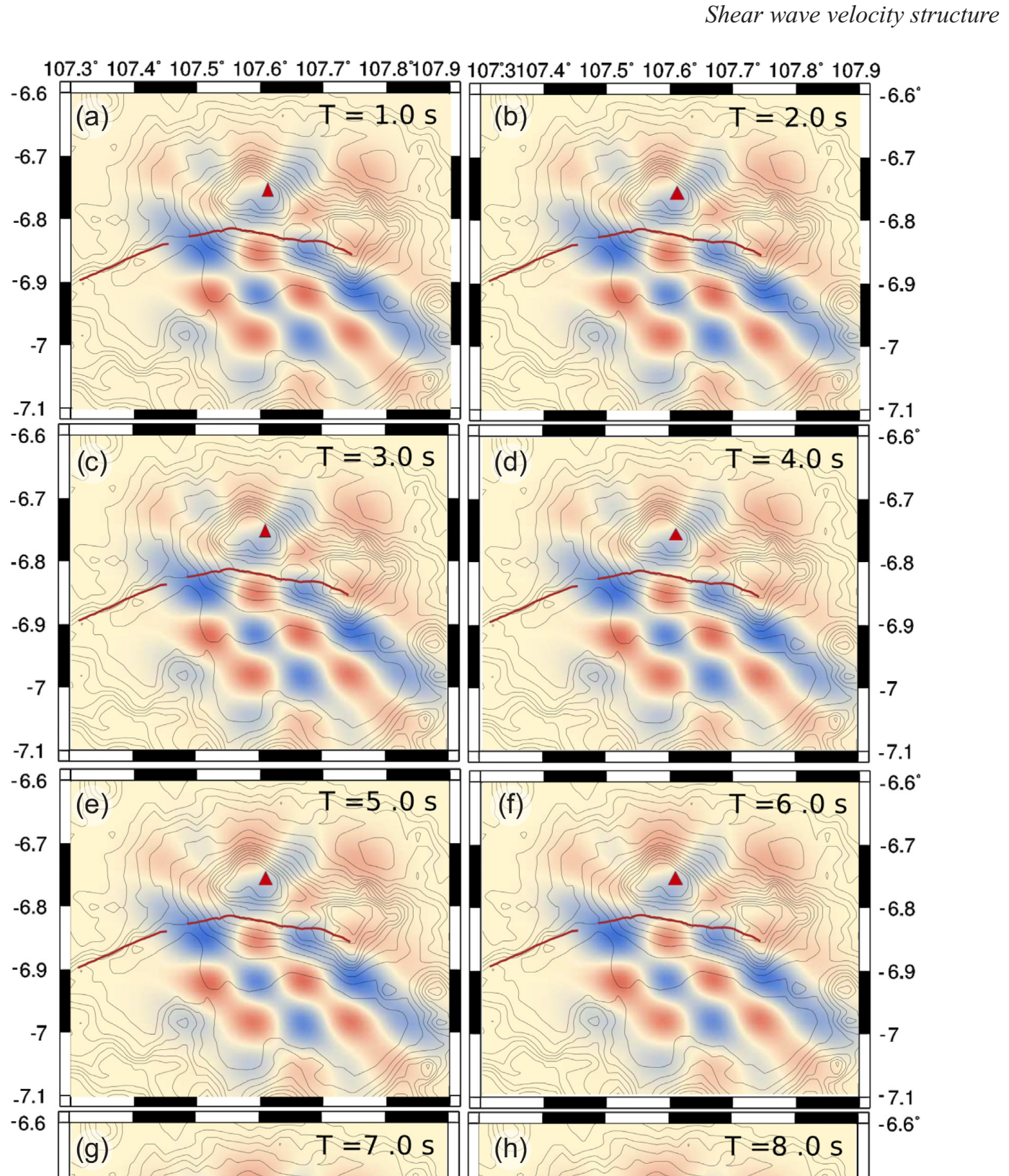
$-6.6^{\circ}$
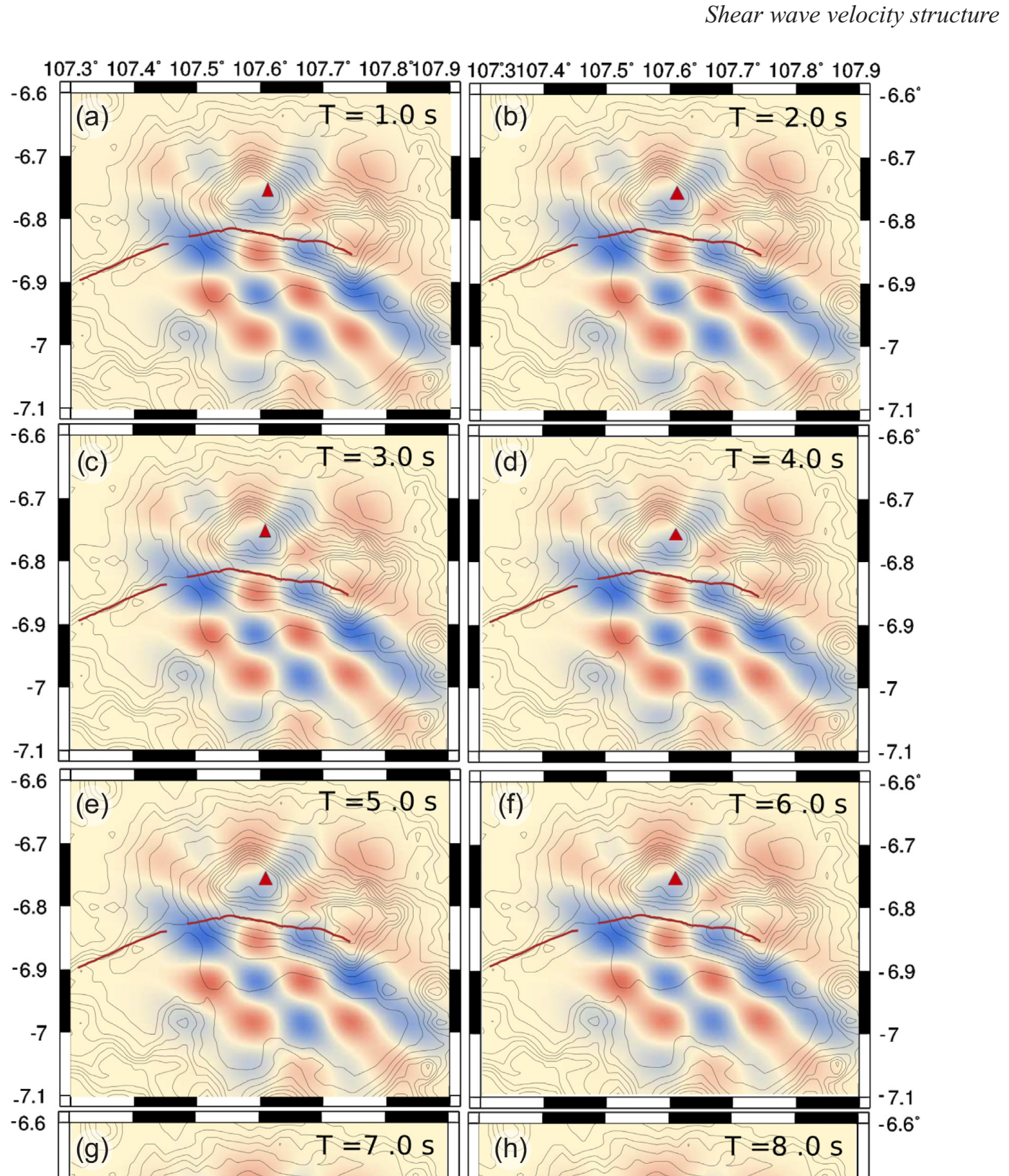

(f)

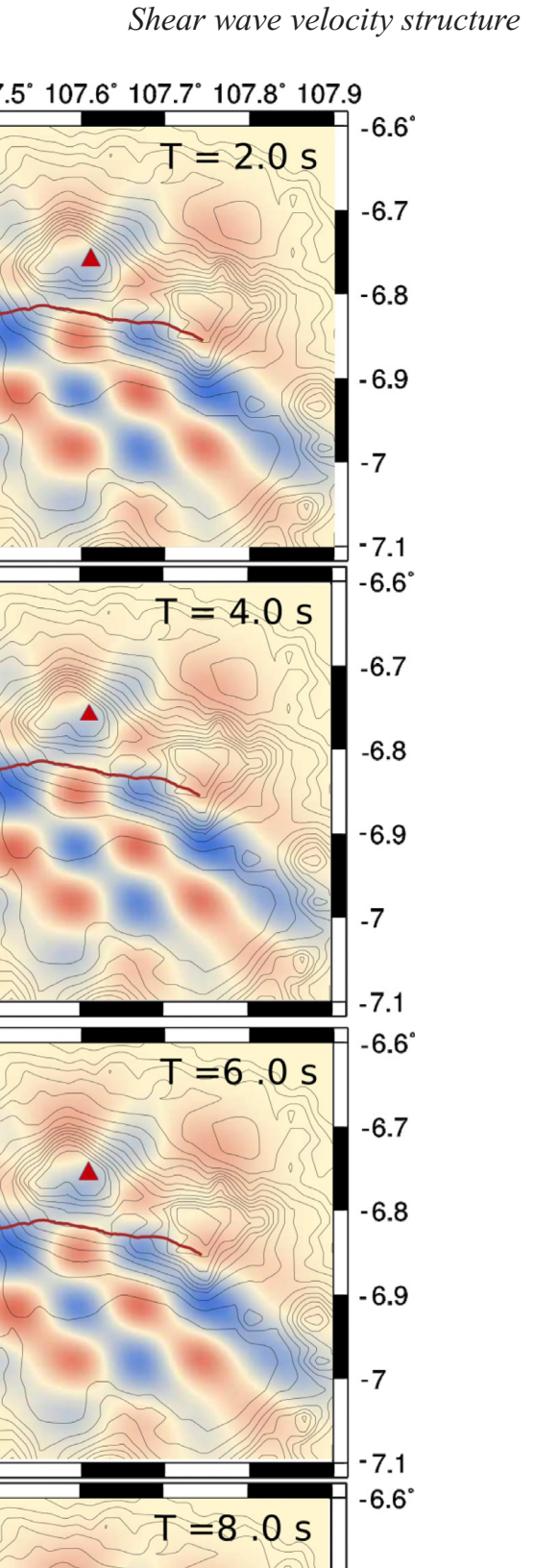

$-7.1$

$-6.6$

(g)

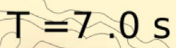

$T=7.0 \mathrm{~s}$

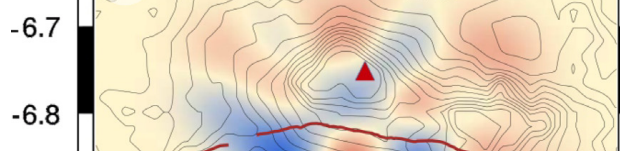

I
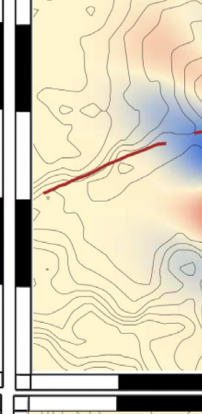

(h)
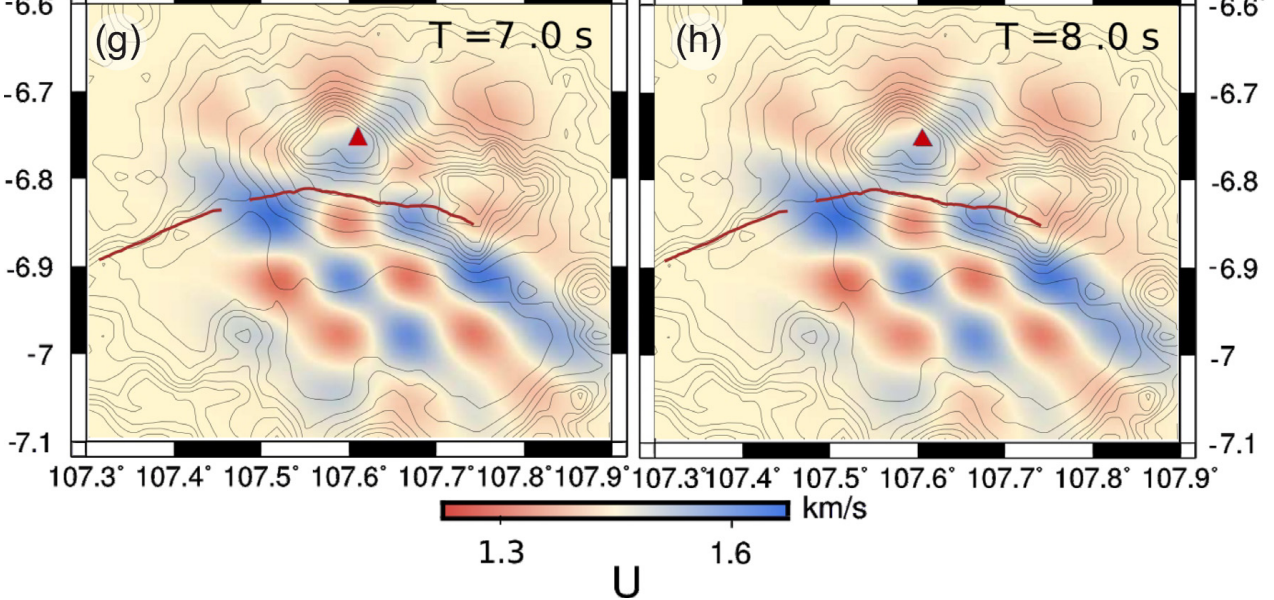

Figure 3. Checkerboard test at $T=1-8 \mathrm{~s}$ using damping and smoothing factors of 200. Red triangle depicts the Tangkuban Parahu volcano and red lines depict the northeastern part of the Cimandiri Fault and the Lembang Fault (bold red). Contours are of topography at intervals of $100 \mathrm{~m}$, with the Bandung Basin corresponding to a topographic low in the centre-lower half of the figure, surrounded by the topographic highs extending from Tangkuban Parahu east across the upper part of the figure, as well as along the southern edge of the figure. 

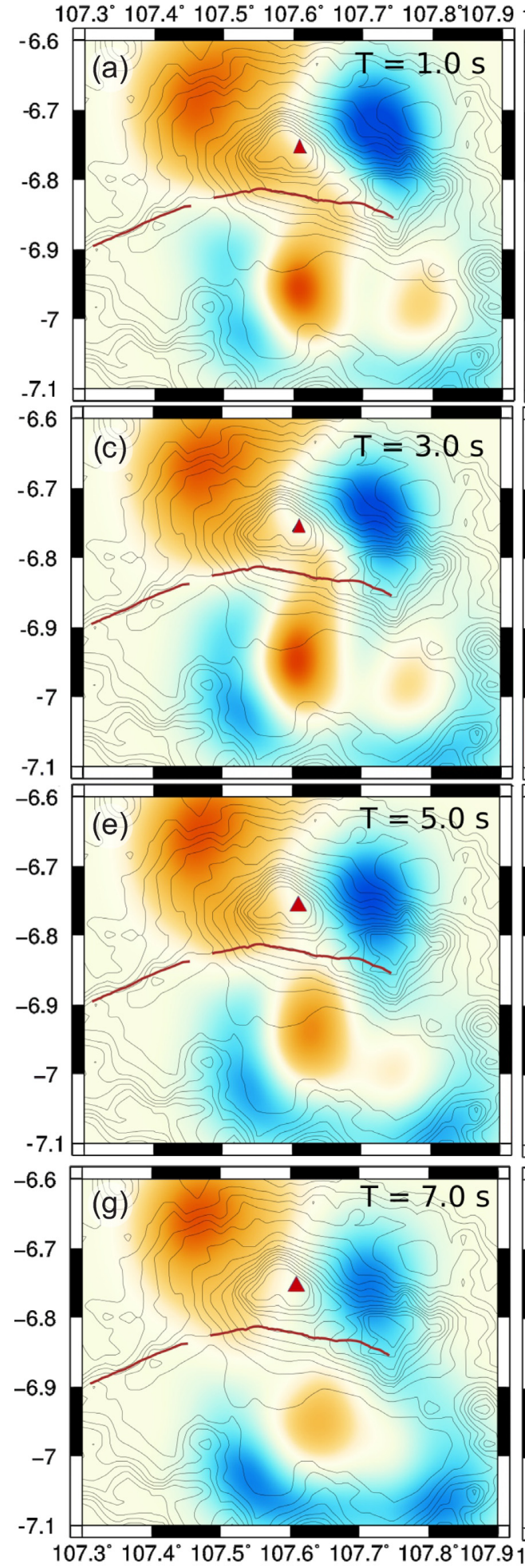

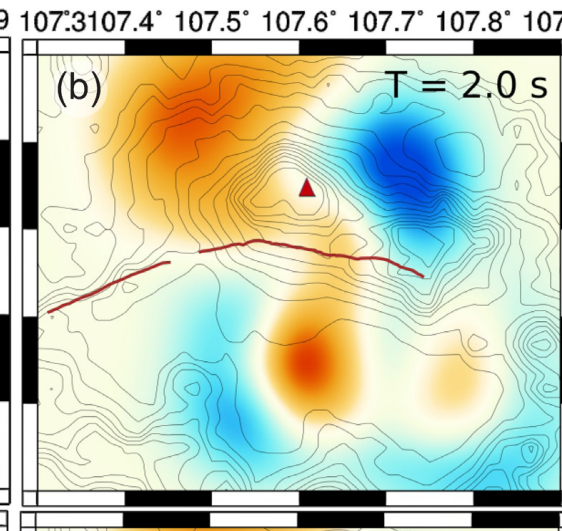
$-6.6^{\circ}$

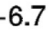

(d)
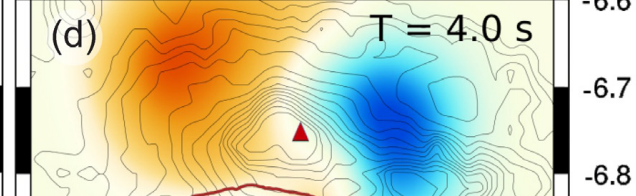

(f)

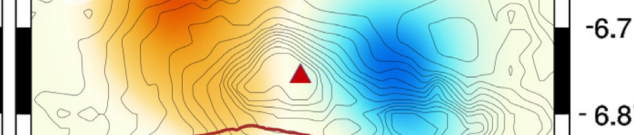

$-6.9$

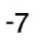

$-7.1$

(h)

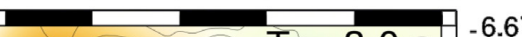

$-6.6^{\circ}$

$-6.7$

$-6.8$

$-6.9$

$-7$

$-7.1$

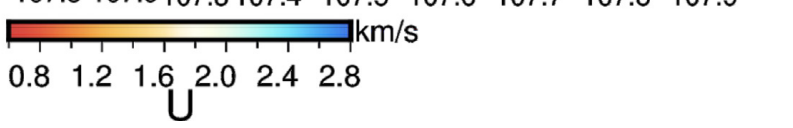

Figure 4. Rayleigh wave group velocity tomograms from subspace inversion of ambient noise at $T=1-8 \mathrm{~s}$.

formation extends under the sediment cover in Ellipse 1, connecting the outcrop at its northern and southern ends. This is responsible for the relatively high $V_{s}$ there at $1 \mathrm{~km}$ depth, despite the surface geology indicating the presence of sedimentary basin fill.
Our $V s$ model also reveals the depth and lateral extent of the Bandung Basin, as well as pronounced differences in the character of its western and eastern parts (Ellipse 2 in Fig. 6, see also Fig. 5d). As can be seen in Figs 5(a) and (c), the $V_{S}$ in the western basin is 
(a)

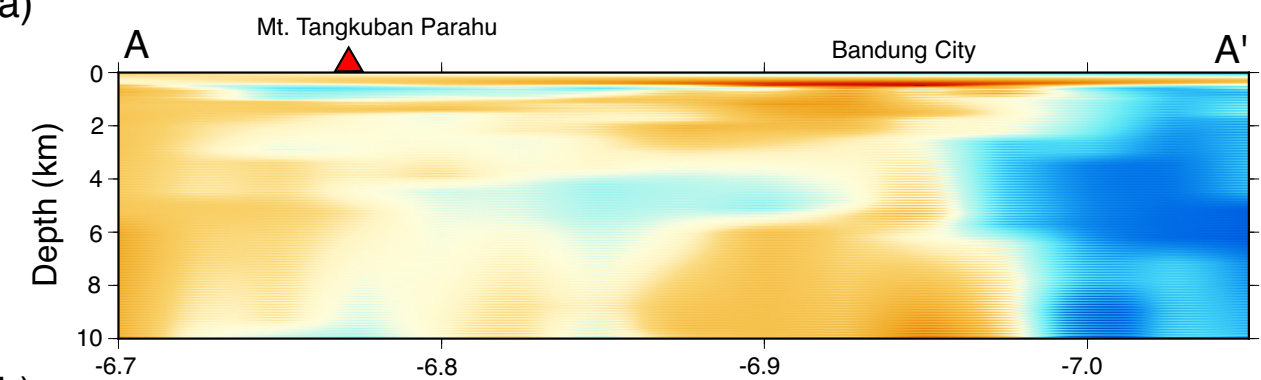

(b)

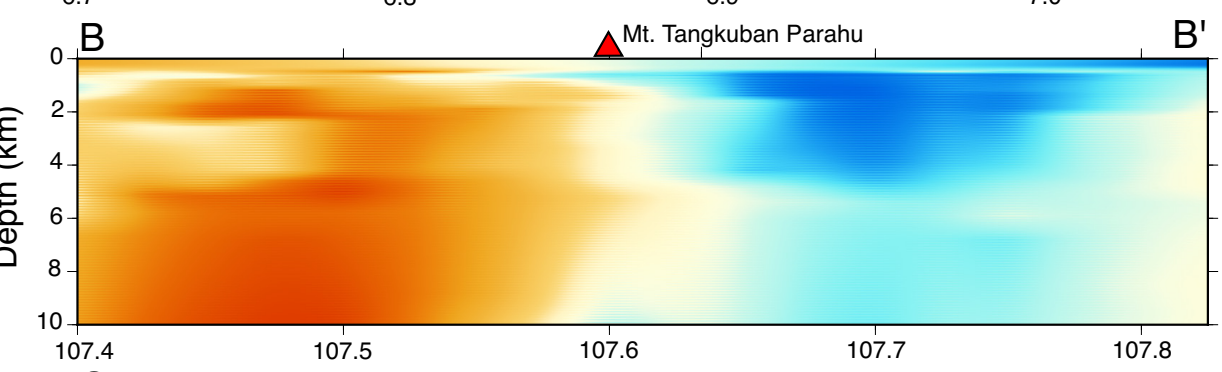

(c)
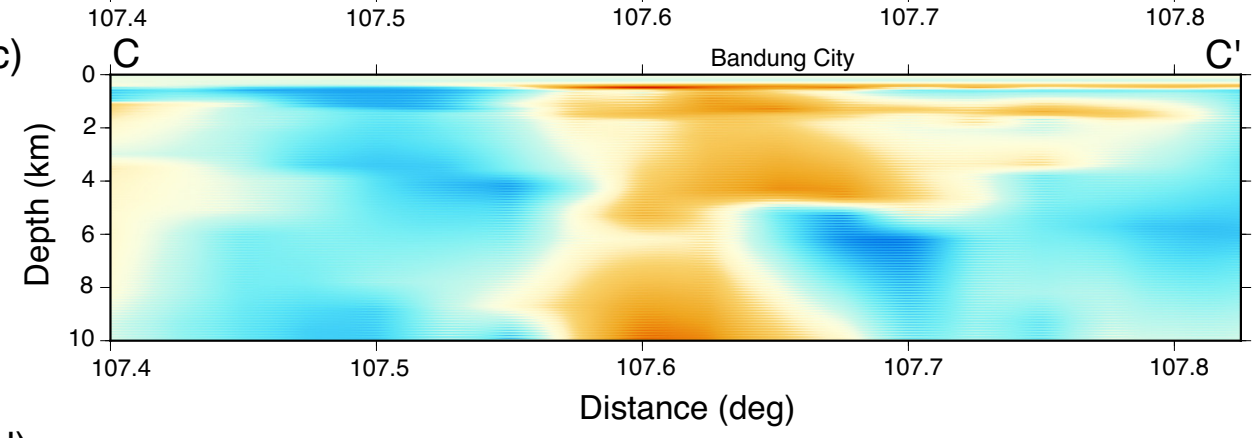

(d)
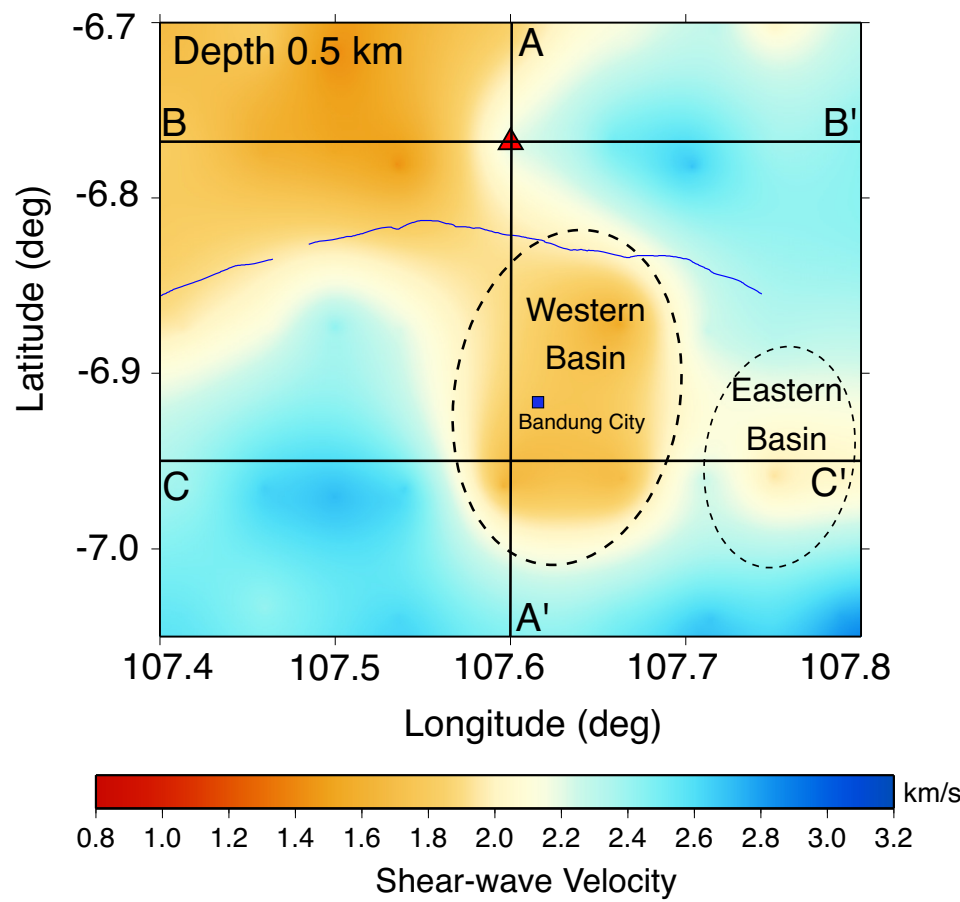

Figure 5. Sections through the 3-D shear wave velocity model of the Bandung Basin: (a) A-A' across the Tangkuban Parahu volcano and Bandung Basin; (b) B-B' across Tangkuban Parahu and (c) C-C' across the Bandung Basin. (d) Plan view of the 3-D Vs model at 0.5 km depth, with positions of the cross-sections in (a)-(c) indicated. The two dashed Ellipses denote the extent of the western and eastern parts of the Bandung Basin. 


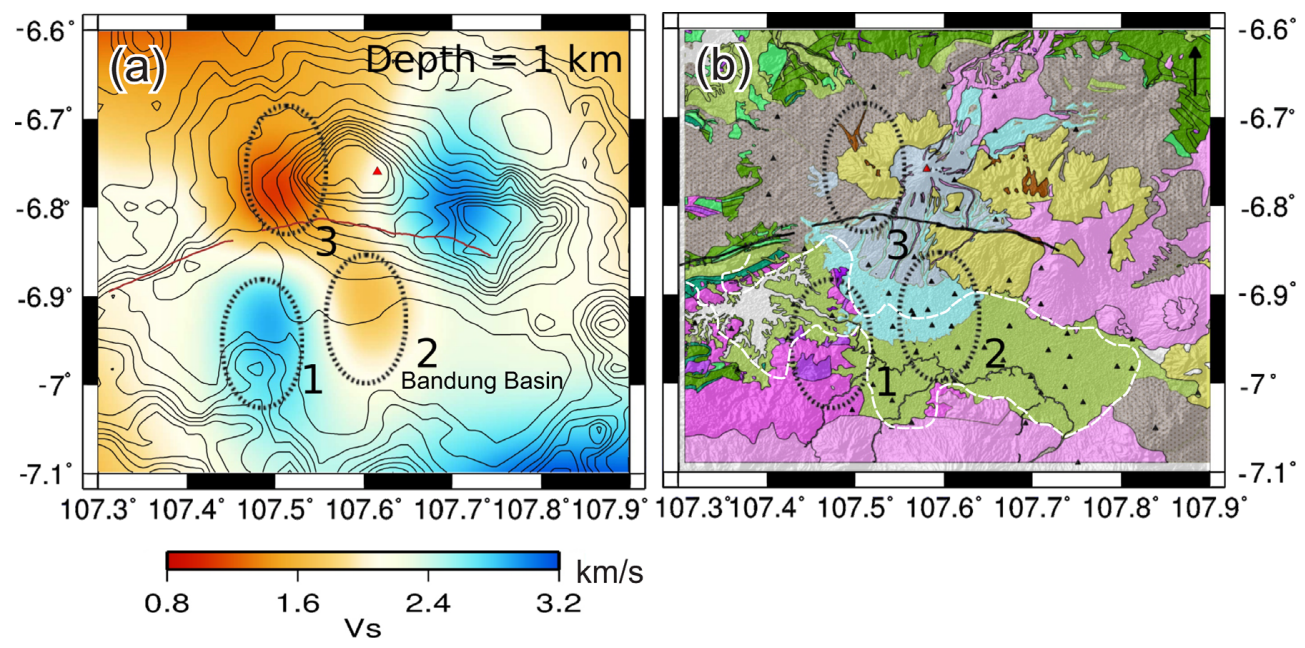

Figure 6. (a) Shear wave velocity map at depth $=1 \mathrm{~km}$ versus (b) the surface geological map of the Bandung Basin as shown in Fig. 1(a). Ellipses $1-3$ indicate the features of the $V s$ tomogram that correlate with the surface geology.

lower than $1 \mathrm{~km} \mathrm{~s}^{-1}$, and its depth is $1 \mathrm{~km}$ or less, except in its central part where it may reach as deep as $1.5 \mathrm{~km} \mathrm{~s}^{-1}$. In the eastern basin, the $V s$ anomaly is much less pronounced. Although $V s$ in the eastern basin does not appear to be less than $1.5 \mathrm{~km} \mathrm{~s}^{-1}$, it seems likely that the lacustrine sediments there actually have much lower $V s$, but that their thickness is less than the resolution of our model, so that the apparent $V_{S}$ in the eastern basin is a combination of sediment and basement $V S$. These differences are very consistent with our understanding of the history of the Bandung Basin, in that since $105 \mathrm{ka}$ the high relief of the eastern part of the Lembang Fault (see Figs 5d and 6) has acted as a topographic barrier shielding the eastern basin from volcaniclastic sediment from Tangkuban Parahu. Thus, the eastern part of the basin has experienced mainly lowintensity lacustrine sedimentation. The western basin, by contrast, has experienced catastrophic volcaniclastic sedimentation that has flowed unimpeded from Tangkuban Parahu into the western part of the basin, thereby developing a much thicker accumulation of basement fill (Dam 1994; Dam et al. 1996; Daryono et al. 2019). The remaining, very low velocity zone (Ellipse 3 ) on the upper western slope of Tangkuban Parahu, is suspected to be a layer of volcanic eruption products trapped in the valleys on the outskirts of the Tangkuban Parahu volcano's summit ( $c f$. Dam et al. 1996).

In Fig. 7, we show a 3-D representation of our $V s$ model for the Bandung area to further explore the spatial relationships among the $V s$ anomalies in the model. It can be seen from Fig. 7 just how thin a feature the Bandung Basin is compared to the other $V_{S}$ anomalies, in particular, the massive low $V s$ anomaly that extends downwards and westward from the summit of Tangkuban Parahu. We interpret this large $V s$ anomaly as being associated with fluids and/or partial melt, similar to that which has been shown to exist beneath Mt Merapi in central Java (Lühr et al. 2013). We also note the existence of two low- $V s$ anomalies at around 4 and $10 \mathrm{~km}$ depth directly beneath the Bandung Basin, for which we know of no obvious interpretation.

\section{CONCLUDING REMARKS}

We have demonstrated that a relatively straightforward application of ANT to data from a temporary broadband seismic deployment in an urban environment in Indonesia can image structure in the upper crust that is of potential interest in further volcanological and earthquake hazard studies of the Bandung area.

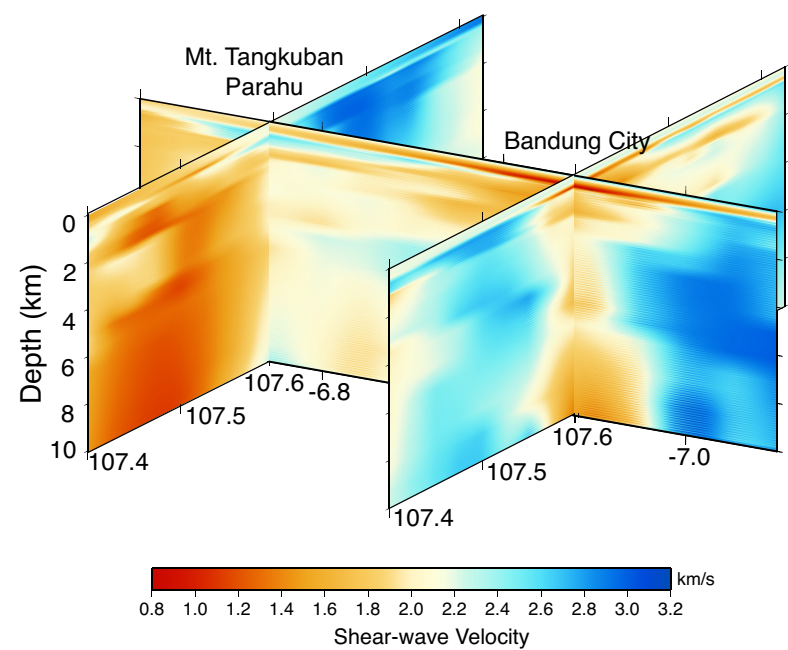

Figure 7. 3-D representation of our $V s$ model beneath the study region. Notice the massive low $V s$ anomaly to the west of the Tangkuban Parahu, which may be correlated with the Sunda volcano existed during Pleistocene age, as well as the very thin and very low velocity beneath Bandung City, which we interpret as basin fill.

Understanding the structure and extent of the Bandung Basin is critical to understanding seismic hazard because of the potential for amplification and resonance of seismic waves. While the structure imaged here may be too coarse to quantify the amplification at frequencies important for low-rise residential structures, it may allow modelling of basin effects at $1 \mathrm{~Hz}$ and below, frequencies that are important for high-rise buildings, such as has been considered for Jakarta by Cipta et al. (2018b) and in Mexico City by Cruz-Atienza et al. (2016). This is especially important given the proximity of the Lembang Fault, which skirts Bandung to the north. Daryono et al. (2019) have shown that the Lembang Fault has ruptured in the prehistoric past as recently as the 15 th century, and could host an earthquake of magnitude 6.5-7.0. Moreover, it may be possible to combine the ANT used here with techniques such as horizontal-tovertical spectral ratio (HVSR) and autocorrelation of seismic noise, as has been used in Jakarta by Cipta et al. (2018a) \& Saygin et al. (2017), to increase the depth resolution of our $V_{s}$ model and thereby extend the frequency range at which seismic waves can be modelled. 
Similarly, while our ANT result for $V S$ structure beneath Tangkuban Parahu volcano is too coarse to confidently identify any magma plumbing system, our preliminary $V s$ model can serve as a guide to more detailed tomographic studies such as that conducted by Widiyantoro et al. (2018) on Mt Merapi, which was able to elucidate the plumbing system and explain the explosive potential of eruptions there. Although Kartadinata et al. (2002) have shown that the style of eruptions at Tangkuban Parahu changed from magmatic/phreatomagmatic to phreatic at about $10000 \mathrm{BP}$, its current potential for experience magmatic eruptions is unknown.

\section{ACKNOWLEDGEMENTS}

$\mathrm{BP}$ is very grateful to $\mathrm{BMKG}$ for a doctoral scholarship during his study at the Institut Teknologi Bandung (ITB). The data used in this study were acquired using the research funding from the Australian Research Council Linkage Project LP110100525, partially supported by the Australian Aid program of the Australian Dept. Foreign Affairs and Trade. This study was also partially funded by the Indonesian Ministry of Research, Technology and Higher Education under WCU Program 2019 managed by ITB awarded to S. Widiyantoro. We thank A. Morelli, S. Schippkus and an anonymous reviewer for helpful comments and suggestions that improve the manuscript considerably. We used the Generic Mapping Tools (Wessel \& Smith 1998) and Quantum GIS (https://qgis.org) to create figures presented in this study.

\section{REFERENCES}

Alzwar, M., Akbar, N. \& Bachri, S., 1992. Geological Map of the Garut and Pameungpeuk Quadrangle, Java. Geological Research and Development Centre, Bandung, Indonesia.

Bensen, G.D., Ritzwoller, M.H. \& Shapiro, N.M., 2008. Broadband ambient noise surface wave tomography across the United States, J. geophys. Res., 113, doi:10.1029/2007JB005248.

Bronto, S. \& Hartono, U., 2006. Potensi sumber daya geologi di daerah Cekungan Bandung dan sekitarnya, J. G. Indonesia, 1(1), Bandung. (in Indonesian), doi:10.17014/ijog.1.1.9-18.

Cipta, A., Cummins, P., Dettmer, J., Saygin, E., Irsyam, M., Rudyanto, A. \& Murjaya, J., 2018a. Seismic velocity structure of the Jakarta Basin, Indonesia, using trans-dimensional Bayesian inversion of horizontal-tovertical spectral ratios, Geophys. J. Int., 215(1), 431-449.

Cipta, A., Cummins, P., Irsyam, M. \& Hidayati, S., 2018b. Basin resonance and seismic hazard in Jakarta, Indonesia, Geosciences, 8(4), 128, doi:10.3390/geosciences8040128.

Cruz-Atienza, V.M., Tago, J., Sanabria-Go'mez, J.D., Chaljub, E., Etienne, V., Virieux, J. \& Quintanar, L., 2016, Long duration of ground motion in the paradigmatic Valley of Mexico, Nature, 6, 38807, doi:10.1038/srep38807.

Dam, M.A.C., 1994. The Late Quaternary Evolution of The Bandung Basin, West Java, Indonesia, Dissertation, Department of Quaternary Geology, Faculty of Earth Sciences, Vrije University, Amsterdam, Unpublished, 252pp.

Dam, M.A.C., Suparan, P., Nossin, J.J. \& Voskuil, R.P.G.A., 1996. A chronology for geomorphological developments in the greater Bandung area, West-Java, Indonesia, J. Southeast Asian Earth Sci., 14(1-2), 101-115.

Daryono, M.R., Natawidjaja, D.H., Sapiie, B. \& Cummins, P., 2019. Earthquake geology of the Lembang Fault, West Java, Indonesia, Tectonophysics, 751, 180-191.

Dunkin, J.W., 1965. Computation of modal solutions in layered, elastic media at high frequencies, Bull. seism. Soc. Am., 55, 335-358.

Herrmann, R.B., 1973. Some aspects of band-pass filtering of surface waves, Bull. seism. Soc. Am., 63, 663-671.
Kang, T.S. \& Shin, J.S., 2006. Surface-wave tomography from ambient seismic noise of accelerograph networks in southern Korea, Geophys. Res. Lett., 33, 1-5.

Kartadinata, M.N., Okuno, M., Nakamura, T. \& Kobayashi, T., 2002. Eruptive history of Tangkuban Perahu Volcano, West Java, Indonesia: a preliminary report archived 2006-08-23 at the Wayback Machine, J. Geography, 111(3), 404-409.

Kennett, B.L.N., Sambridge, M.S. \& Williamson, P.R., 1988. Subspace methods for inverse problems with multiple parameter classes, Geophys. J. Int., 94, 237-247.

Kennett, B.L.N., Engdahl, E.R. \& Buland, R.P., 1995. Constraints on seismic velocities in the Earth from travel times, Geophys. J. Int., 122, 108-124.

Koesmono, M.,Kusnama \& Suwarna, N., 1996. Peta Geologi Lembar Sindangbarang dan Bandarwaru, Jawa skala 1:100.000 edisi ke-2, Puslitbang Geologi, Bandung. (in Indonesian).

Lévêque, J.-J., Rivera, L. \& Wittlinger, G., 1993. On the use of the checkerboard test to assess the resolution of tomographic inversions. Geophys. $J$. Int., 115, 313-318.

Li, H., Bernardi, F. \& Michelini, A., 2010. Surface wave dispersion measurements from ambient seismic noise analysis in Italy, Geophys. J. Int., 180, 1242-1252.

Li, H., Su, W., Wang, C. \& Huang, Z., 2009. Ambient noise Rayleigh wave tomography in western Sichuan and eastern Tibet, Earth planet. Sci. Lett., 282, 201-211.

Lin, F.C., Moschetti, M.P. \& Ritzwoller, M.H., 2008. Surface wave tomography of the western United States from ambient seismic noise: Rayleigh and Love wave phase velocity maps, Geophys. J. Int., 173(1), 281-298.

Lühr, B.G., Koulakov, I., Rabbel, W., Zschau, J., Ratdomopurbo, A., Brotopuspito, K.S., Fauzi, P. \& Sahara, D.P., 2013. Fluid ascent and magma storage beneath Gunung Merapi revealed by multi-scale seismic imaging, J. Volc. Geotherm. Res., 261, 7-19.

Martha, A.A., Cummins, P., Saygin, E., Widiyantoro, S. \&Masturyono, 2017. Imaging of Upper Crustal Structure beneath East Java Bali, Indonesia with ambient noise tomography, Geosci. Lett., 4(14), doi:10.1186/s40562-017-0080-9.

Rawlinson, N. \& Sambridge, M., 2004a. Wavefront evolution in strongly heterogeneous layered media using the fast marching method, Geophys. J. Int., 156, 631-647.

Rawlinson, N. \& Sambridge, M., 2004b. Multiple reflection and transmission phases in complex layered media using a multistage fast marching method, Geophysics, 69, 1338-1350.

Sabra, K.G., Gerstoft, P., Roux, P., Kuperman, W.A. \& Fehler, M.C., 2005. Surface wave tomography from microseism in southern California, Geophys. Res. Lett., 32, L14311, doi:10.1029/2005GL023155.

Sambridge, M., 1999a. Geophysical Inversion with a Neighborhood Algorithm I: searching a parameter space, Geophys. J. Int., 138, 479-494.

Sambridge, M., 1999b. Geophysical Inversion with a Neighborhood Algorithm II: appraising the ensemble, Geophys. J. Int., 138, 727-746.

Saygin, E. \& Kennett, B.L.N., 2010. Ambient seismic noise tomography of Australian continent, Tectonophysics, 481, 116-125.

Saygin, E. \& Kennett, B.L.N., 2012. Crustal structure of Australia from ambient seismic noise tomography, J. geophys. Res., 117, B01304, doi:10.1029/2011JB008403.

Saygin, E. et al., 2016. Imaging architecture of the Jakarta Basin, Indonesia with transdimensional inversion of seismic noise, Geophys. J. Int., 204(2), 918-931.

Saygin, E., Cummins, P.R. \& Lumley, D., 2017. Retrieval of the P-wave reflectivity response from autocorrelation of seismic noise: Jakarta Basin, Indonesia, Geophys. Res. Lett., 44, 792-799.

Shapiro, N.M., Campillo, M., Stehly, L. \& Ritzwoller, M.H., 2005. High resolution surface-wave tomography from ambient seismic noise, Science, 307, 1615-1618.

Silitonga, P.H., 1973. Geological Map of the Bandung Quadrangle, Java, Geological Research and Development Centre, Bandung, Indonesia.

Stankiewcz, J., Ryberg, T., Haberland, C.,Fauzi \& Natawidjaja, D.H., 2010. Lake Toba volcano magma chamber imaged by ambient seismic noise tomography, Geophys. Res. Lett., 37(17), L17306, doi:10.1029/2010GL044211. 
Suhari, S. \& Siebenhüner, M., 1993. Environmental Geology for Land Use and Regional Planning in Bandung Basin, West Java, Indonesia Directory of Environmental Geology (DEG), Bandung, Indonesia.

Sujatmiko, 1972. Geological Map of the Cianjur Quadrangle, Java, Geological Research and Development Centre, Bandung, Indonesia.

Van Bemmelen, R.W., 1949. The Geology of Indonesia, Government Printing Office, The Hague.

Wald, D. \& Allen, T., 2007. Topographic slope as a proxy for seismic site conditions and amplification, Bull. seism. Soc. Am., 97(5), 1379-1395.

Wathelet, M., Jongmans, D., Ohrnberger, M. \& Bonnefoy-Claudet, S., 2008. Array performances for ambient vibrations on a shallow structure and consequences over Vs inversion, J. Seismol., 12, 1-19.

Wessel, P. \& Smith, W.H.F., 1998. New, improved version of Generic Mapping Tools Released, EOS, Trans. Am. Geophys. Un., 79, 579, doi: 10.1029/98EO00426.

Widiyantoro, S. et al., 2018. Seismic imaging and petrology explain highly explosive eruptions of Merapi Volcano, Indonesia, Sci. Rep., 8(1), 13656, doi:10.1038/s41598-018-31293-w.

Yang, Y., Ritzwoller, M.H., Levshin, A. L. \& Shapiro, N.M., 2007. Ambient noise Rayleigh wave tomography across Europe, Geophys. J. Int., 168, 259-274.

Yudistira, T. \& Widiyantoro, S., 2016. Characteristics of seismic noise in Central Java, Indonesia, in AIP Conference Proceedings 1730, 020013, doi:10.1063/1.4947381.

Zulfakriza, Z., Saygin, E., Cummins, P.R., Widiyantoro, S., Nugraha, A.D., Lühr, B.-G. \& Bodin, T., 2014. Upper crustal structure of central Java, Indonesia, from transdimensional seismic ambient noise tomography, Geophys. J. Int., 197, 630-635.

\section{SUPPORTING INFORMATION}

Supplementary data are available at $G J I$ online.

Figure S1. An example of frequency-time analysis of Green's function between BNA03 and BNA09 with a distance of $\sim 4 \mathrm{~km}$ for the extraction of group velocity.

Figure S2. Ray path distribution at $T=1-8 \mathrm{~s}$ using damping and smoothing factors of 100 and 100 , respectively.

Figure S3. Checkerboard test at $T=1-8 \mathrm{~s}$ as in Fig. 3 but with different cell sizes.

Figure S4. Depth profiles of shear wave velocity obtained using the Neighborhood Algorithm at points 169, 171 and 173 located in the Bandung Basin. The colour of the model space represents the density distribution of samples. The solid black lines in the middle correspond to the best-fitting models. Locations of the grid points are shown in the lower panel.

Figure S5. Shear wave velocity maps at depths $=1-8 \mathrm{~km}$ from the Neighborhood Algorithm inversion of group velocity dispersion curves. Red triangle depicts the Tangkuban Parahu volcano and red lines depict the northeastern part of the Cimandiri Fault and the Lembang Fault (bold red).

Figure S6. 3-D representation of our $V S$ model beneath the study region. The location of Lembang Fault is indicated by the blue line.

Please note: Oxford University Press is not responsible for the content or functionality of any supporting materials supplied by the authors. Any queries (other than missing material) should be directed to the corresponding author for the paper. 